\title{
Cartographic image of immaterial elements in a city on the example of city maps of Warsaw from 1641 until the end of the 19th century
}

\begin{abstract}
The article discusses the problem of cartographic presentation of immaterial elements of city space. On the example of old city maps of Warsaw from the period between 1641 and the end of the 19th century, the image of objects and places in Warsaw is linked to the image of activities happening in them, or in connection with them. The author presents results of the analysis of the methods of presentation of immaterial elements, distinguishing three most numerous groups of them: nomenclature, functions and significance of objects, and property and administrative issues. The conclusions base on the analysis of 61 general city maps of Warsaw covering the whole city, elaborated in the periods 1641-1800, 1801-1900, and, supplementary, 1901-1939.
\end{abstract}

Keywords: history of cartography, Warsaw, immaterial phenomena, old city maps

\section{Introduction}

The city is a spatial phenomenon of three-dimensional physical continuity, containing various elements, both material and immaterial, connected with human activity. Objects and places in a city can be linked to activities happening in them, or in connection with them. Physical objects are accompanied by their immaterial contexts of human activity. If we consider the idea of Bjønnar Olsen (2013) that contemporary study of the world is dominated by anthropocentric methodology, marginalizing the significance of material objects, it seems that in the case of cartographic message it is the opposite. On a map an image of material objects is the dominating contents. It is the image of such objects as streets, buildings, small architecture, hydrographic objects, forms of terrain relief and land cover.

The proposed dichotomic division, although unambiguous at first glance, however raises some doubts. They concern e.g. the cartographic image of places of religious cult. On maps a single sign represents physical objects churches, chapels, cloisters as well as religious activity of believers referring to these places. The designation of the symbol placed on a map is therefore not completely univocal.

Signs presented on general city maps ${ }^{1}$ from the discussed period carry not only topographic contents, but also thematic information referring to immaterial elements which complement the topographic image. Because of the doubling of meaning, in the article I have decided to present also information from the border zone between material and immaterial elements.

\section{Range of research and research hypothesis}

The author presents results of the research on cartographic depiction of immaterial spatial elements existing in a city. Discussion has been limited to Warsaw in the period between 1641 (publication of the first known city map of

\footnotetext{
${ }^{1}$ General geographic city maps are distinguished from maps on which thematic contents is moved to separate reading levels.
} 
Warsaw $^{2}$ ) until the turn of the 20th century. The subject of analysis were general city maps presenting the whole city in its administrative borders, excluding thematic city maps.

61 general city maps of Warsaw were analyzed: 18 from the period 1641-1800, 23 from 1801-1900 and 20 from 1901-1939 (supplementary set).

The initial hypothesis was that on the example of old city maps of Warsaw one can notice successive growth of the number, and therefore also of the role of immaterial objects. However, a precise moment of their first appearance on maps cannot be determined.

\section{Immaterial spatial elements on city maps of Warsaw}

While analyzing 61 city maps of Warsaw elaborated in the period defined above I marked the following types of immaterial elements: area names, street names, object names, religious functions of objects, other functions of objects, significance of objects, property, property numbers, administration, city visions ${ }^{3}$, history, censorship, transportation, judiciary, postal service, healthcare. Some of the above terms are ambiguous, which I mentioned in the introduction. They include, besides religious functions mentioned earlier, such terms as transportation (apart from physical existence of transportation objects), judiciary (apart from the location of court objects). Another term which also requires some explanation is history, within which I also included methods of presentation of phenomena from the past on city maps and variability of elements in time - material elements, obviously. Extension of the problem of understanding the term of immaterial elements is also included in the detailed commentary presented below.

\footnotetext{
2 Varsovia Mosoviae caput et Regia, 1641, Israel Hoppe, scale approx. 1:7500, multi-colour manuscript, $19 \times 33 \mathrm{~cm}$. In: I. Hoppe, 1641, Ordentliche Beschreibung auch historische Erzählung aller fürnemsten begebenheiten, so sich in dem vierjährigen Kriege sechsjährigen Stillestand zwischen denen hochlöblichen krohnen Polen und Schweden anno 1626-1636 incl. Zehn Jahr über im Lande Preussen so offensive als defensive zu Wasser und Lende zugetragen und begeben.

3 The author uses a term equivalent to "spatial planning" which was not used at that time.
}

Three groups of elements which are most frequently presented on old city maps of Warsaw were distinguished:

- nomenclature,

- functions and significance of objects, including religious aspects and services,

- property and administrative aspects, including borders.

Below I present the results of conducted analyses referring to the three groups.

\subsection{Nomenclature}

The term of nomenclature, or city toponymy, urban toponymy, plateonymy, urbonymy or homonymy has been used to define the set of city names since the second half of the 20th century (K. Handke 2009). Three main types of names placed on old city maps of Warsaw are street names, area names and names of particular objects. The oldest use of names on city maps of Warsaw refers to the names of objects. As early as on the second (chronologically) city map of Warsaw known today, which was prepared in 1655 by E. Dahlberg ${ }^{4}$ (B. Krassowski, B. Majewska 1980), we find the first appellative information referring to objects. They are numeral signs ${ }^{5}$, i.e. numbers placed on map and fully explained in the legend. This city map presents: 1. Forum (Market Square), 2. Curia (Townhall), 3. Temp. Parochiale (St. John's collegiate church), 4. Arx Regia (Royal Castle), 5. Atrum (Front Yard of the Castle), 6. Statua R. Sigismondi (King Sigismund's Column), 7. Porta Cracovien.[sis] (Cracow Gate), 8. Porta Zacrociziniensis (Zakroczym Gate), 9. Suburbia (suburbs) and 10. Palatium Principis Caroli Ferdinandi (Palace of Prince Charles Ferdinand Vasa). These names are mostly functional and show partial qualities of proper names only in the case of Zakroczym and Cracow gates. In time this quality would

\footnotetext{
${ }^{4}$ Urbs Warsavia Sedes Regum Poloniæ ordinaria eo statu repræsentata quo à S.R.M. Sueciæ d[ie]. 30. Aug[usti] An.o occupabatu, approx. 1:4000 (40 Prussian rods $-38 \mathrm{~mm}$ ), 1655 , Erik Jönsson Dahlbergh, copperplate, $29.5 \times 22.8 \mathrm{~cm}$. In: Samuel Pufendorf, De rebus a Carolo Gustavo Sueciæ rege gestis, Norymberga 1696.

5 "The usage of the term "numeral sign" for the described single-univocal signs is justified by their function. Similarly, typical signs allow identification of objects, naming objects in this case" (P.E. Weszpiński 2014).
} 
dominate the meaning of the two names, as well as the name of the Market Square (with the extended name of the Old Town Market Square), the Royal Castle and King Sigismund's Column (i.e. The Column of King Sigismund Vasa III). However, this city map does not include already existing street names ${ }^{6}$.

Street names were first presented by C.F. Werneck on two city maps from $1732^{7}$. He marked 14 street names, which was approximately $1 / 4$ of all the names at that time (A. Karczewski 1945). They were not placed on the map, but rather marked with letters explained in the legend. On both maps, one of which is elaborated in French and the other in German, names are either presented in translation or written phonetically. Phonetic transcription is applied to names which are untranslatable or difficult to translate. Examples of such names are Solec - Solec on the French map and Die Solec on the German map, Podwale - respectively Podwal and Die Podwal, Nalewki - Rue Nalewki and Die Nalewki, as well as Leszno - La Lesino and Die Lesna.

More developed nomenclature can be found on C.F. Hübner's city map from $1740^{8}$ where beside 33 proper names of streets and names showing directions of outbound roads there are also names of areas and objects. The author marked i.a. names of juridictions (historically - privately owned tracts of land within a municipality) Grybów (correctly Grzybów) and Wielopole, names Thier Garten (Zwierzyniec), Dorff Ujasdoff (village Ujazdów), Das Bath (Łazienki), as well as Mistberg (the first cartographic description of Gnojna Góra). The method of description of inbound and outbound roads is intriguing. They are "roads to",

\footnotetext{
${ }^{6}$ Information of over 40 names can be found in Rewizja Miasta Starey i Nowey Warszawy (Revision of the city of Old and New Warsaw) from 1659.

7 Plan de Varsovie fait par ordre de son Excellence Monseigneur le Comte de Bielinski Maréchal de la Cour per le major Werneck Anno 1732, approx. 1:1800 - 1:4200, 1732, C.F. Werneck, multi-colour manuscript, lost (a black and white photocopy exists), original dimensions unknown.

8 Plan der Koenigl. Pohl. Residenz Stadt Warschau nebst allen daselbst befindlichen Palais und Vorstædten, wie auch dabey gelegenen Szolec, Anno 1733 außgemeßen, und Anno 1740. mit Nachtragung, derer binen dieser Zeit Vorgegefallenen Verænderungen nochmals gezeichnet von C.F. Hübner ing: Cap:, approx. 1:10,000 (1500 Dresd. Ellen - $97 \mathrm{~mm}), 1740$, Carl Federick Hübner, multi-colour manuscript, $78.4 \times 43.2 \mathrm{~cm}$.
}

e.g. Weg nach Maria Mont $u$. Bilana (Road to Marymont and Bielany), Weg nach Wahl Plac (road to the Election Field), or "roads from", e.g. Weg von Czerniakow (road from Czerniaków), Straaße von Piaseczna (road from Piaseczno). The rule governing the application of the two forms of description of directions has not been determined yet. A similar solution we will encounter also on later city maps, i.a. J.G. Lehmann's from $1809^{9}$ (P.E. Weszpiński 2012, 2013). C.F. Hübner, similarly to C.F. Werneck, used a dual method of describing street names - translation or phonetic transcription. Therefore we find e.g. Johannes Gaße (Świętojańska street), Bier Gaße (Piwna street), Brücke Gaße (Mostowa street), Neue Welt (Nowy Świat street), but also untranslated Groß Szolec (Solec street), Nalifki (Nalewki street), Lescino (Leszno street). Translated names will be gradually replaced with the original nomenclature, to finally phase out by the end of the 18th century. Last examples of usage from 1831 can be seen only as relics of this solution. Translation of names into Russian in the second half of the 19th century is yet another case, for it resulted from the requirement of writing names in the official language of the Russian Empire.

Due to synthetic character of the article I do not further develop detailed discussion of the presentation of nomenclature. Presented examples illustrate the introduction and character of the main methods of presenting toponomastic issues on old city plans of Warsaw.

The analysis of the methods of presentation of nomenclature on old city maps of Warsaw leads to a number of significant conclusions. Names seem to answer the key question "what is the name of the object", therefore referring to immaterial features of the city space to which nomenclature refers. This is information at nominal level, and only a few city maps attempt to move information to higher levels of measurment. Attempts at classification can be seen e.g. on Maciej Deutsch's city map from $1777^{10}$, where the names of more significant

\footnotetext{
${ }^{9}$ Plan Miasta Warszawy. Plan von der Stadt Warschau, approx. 1:11,700 (1500 Toisen - $25 \mathrm{~cm} / 5000$ Dres. Ellen $24.2 \mathrm{~cm}), 1809$, Johann Georg Lehmann, engraved by Joseph Bach, copperplate, $93 \times 67 \mathrm{~cm}$.

10 Planta Miasta Warszawy z okolicami 1777, 1:21,000 (4000 ells - $111 \mathrm{~mm}), 1777$, Maciej Deutsch, multi-colour
} 
settlements ${ }^{11}$ around Warsaw are written in boldface. In 1809 J.G. Lehmann also attempted to introduce classification of names on a city plan of Warsaw, however his solution found no followers.

Old city maps of Warsaw often show a relatively wide variety of caption sizes. A superficial analysis could lead to a conclusion about classifying character of these differences. However, they are actually a result of a graphic attempt to adapt caption size to the width of streets presented on the map. It seems that larger lettering in the names of large streets (clearly visible on J.G. Lehmann's map from 1809 and on the city map by Military Engineers' Corps and their followers in the years 1822-1859) is due to more available space rather than an attempt at graphic presentation of street classification (H. Bartoszewicz, P.E. Weszpiński 2017). On the plans where streets were of the same width there were no attempts to apply different sizes of captions which could carry additional information.

Two methods of caption placement were used on old city maps of Warsaw: either a letter or a sign placed on the map and explained outside of the frame, or a full caption placed on the map, within the sign of the street or above it. Usage of letters and signs was gradually phased out until its almost complete disappearance by the middle of the 19th century.

Although in the 17th century nomenclature on city maps of Warsaw was practically omitted and in the middle of the 18th century it was marginal (in 1732 only approximately $1 / 4$ of street names were given), this attitude was reversed at the end of the 18th century. As a result of this process on the plans by P. Hennequin and G. von Rauch from 1796 almost $90 \%$ of street names are presented. At the same time there is no relation between the growing number of presented street names and the scale of the map. The number of names on selected city maps is shown in table 1.

In the context of discussing nomenclature some interesting conclusions may be drawn from the figures in figure 1 . The share of plans containing street and area names is increasing in time, while the share of plans presenting

\footnotetext{
manuscript, $114.8 \times 130.5 \mathrm{~cm}$.

11 The author of the city map did not clarify the applied differentiation.
}

Table 1. The number of street names on selected city maps of Warsaw

\begin{tabular}{|l|c|}
\hline \multicolumn{1}{|c|}{ City maps of Warsaw } & $\begin{array}{c}\text { Number } \\
\text { of street } \\
\text { names }\end{array}$ \\
\hline C.F. Werneck (1732) & 14 \\
\hline C.F. Hübner (1740) & 33 \\
\hline $\begin{array}{l}\text { P. Ricaud Tirregaille - „great map” } \\
\text { (1762) }\end{array}$ & 31 \\
\hline $\begin{array}{l}\text { P. Ricaud Tirregaille - „small map” } \\
\text { (1762) }\end{array}$ & 32 \\
\hline G.L. le Rouge (1768) & 26 \\
\hline G.A. Rizzi-Zannoni (1772) & 13 \\
\hline J.B.L. Aubert, P. Tardieu (1790) & 9 \\
\hline A. Hiż, H. Jędrzejowski (1771) & 192 \\
\hline P. Hennequin (1779) & 193 \\
\hline G. Rauch (1796) & 193 \\
\hline J.G. Lehmann (1809) & 208 \\
\hline L. Scaupae (1831) & 141 \\
\hline W.B. Clarke (1831) & 27 \\
\hline K. Witkowski (1856) & 156 \\
\hline
\end{tabular}

names of particular objects is decreasing. In figure 1 the chronological range of discussion is extended in order to relate data concerning city maps from 1655 until the end of the 19th century to city maps published in the first forty years of the 20th century.

\subsection{Functions and meaning of objects}

In the context of analyzed old city plans of Warsaw it seems reasonable to discuss the function and meaning of objects together. Object functions describe human activity realized within these objects or connected to them. A material sacral object is a place of i.a. religious service, and if it belongs to the military we encounter duty activity of officers and soldiers. Meaning of an object resulting from function or physiognomy actually results from a certain evaluation of the object, and is therefore its immaterial feature. Both these groups of features provide context to the topographic presentation of some objects on a city plan. Its separation could in some cases raise justified doubt, because the meaning of the object is very often derived directly from its function, and therefore from the activity realized within it. The share of city maps in which function and meaning are presented is shown in figure 2 . 


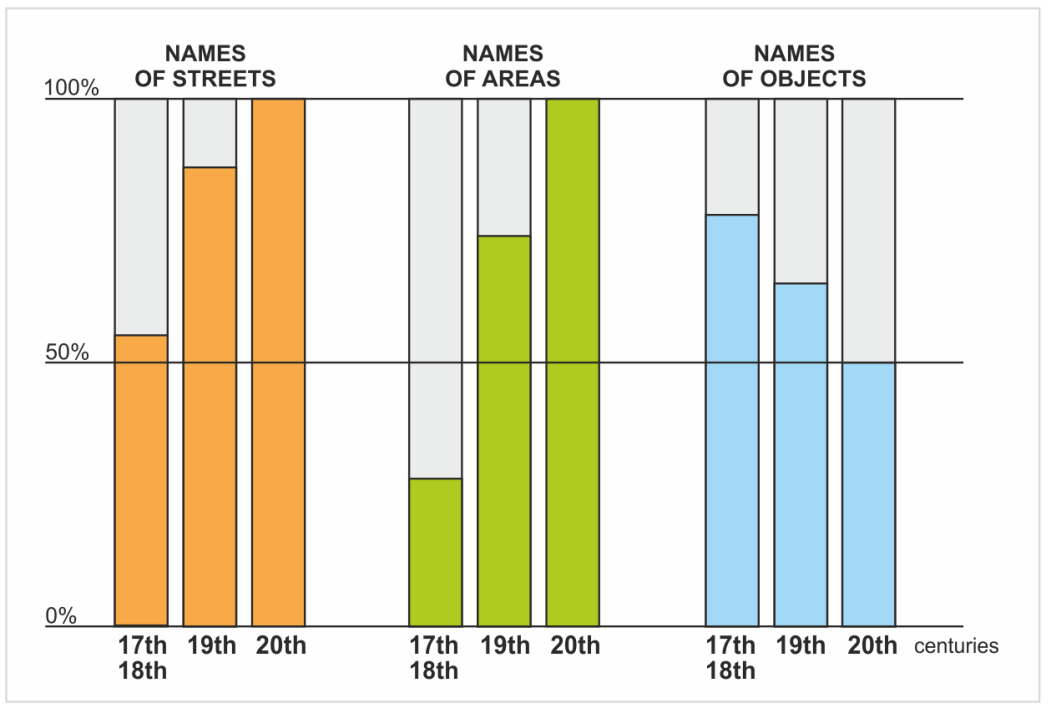

Fig. 1. Percentage of the city maps of Warsaw presenting street, area and object names in the total number of city maps in three periods

The first and most numerous group of presentations of object functions and places of activity on the old city plans of Warsaw were churches, most often shown by placing a cross on the object. The forms of presentation were quite varied, from small crosses within the sign, such as in the case of C.F. Hübner (1740), through large crosses occupying almost the whole sign, as in the case of maps by J.G. Lehmann (1809) and Military Engineers' Corps (1822-1859), to a conventional sign of a cross replacing the projection of the object, as in the

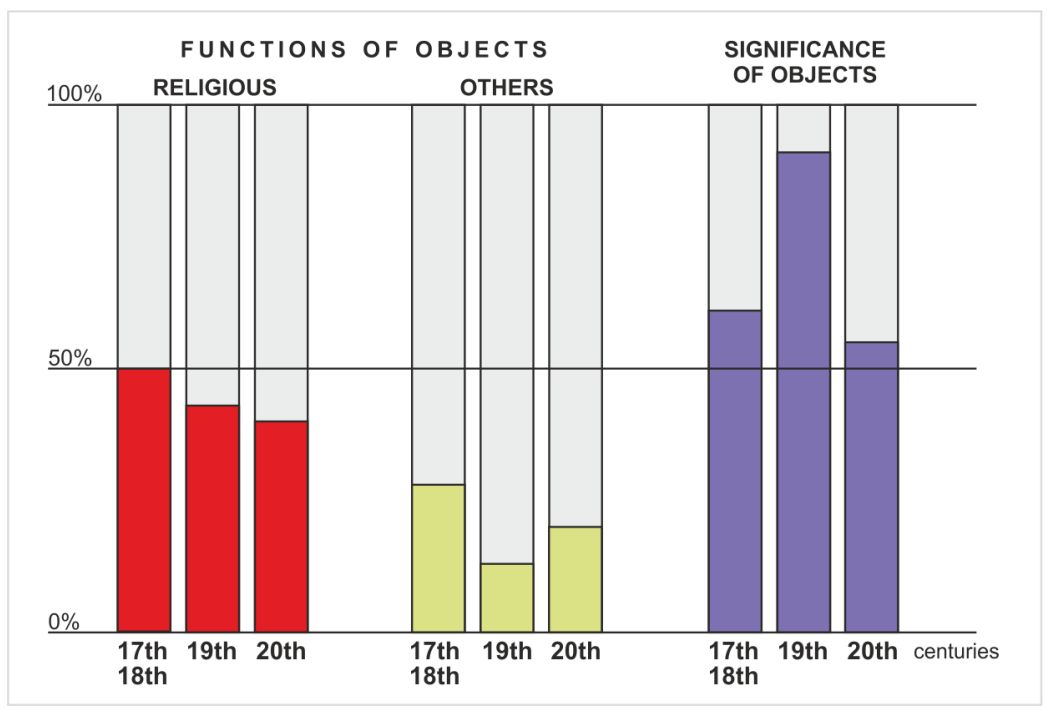

Fig. 2. Percentage of the city maps of Warsaw presenting functions and significance of objects in the total number of city maps in three periods 
case of P. Hennequin (1779). Yet another form of presentation of churches is used on the oldest known city map of Warsaw. In 1641 I. Hoppe (T. Zarębska 1964) marked them with a sign resembling an envelope, perhaps referring to cross-ribbed vault ${ }^{12}$ popular at the time. Both on the maps of I. Hoppe and on the works of the Military Engineers' Corps objects of religious function were given a separate additional color - yellow in the first case, and dark blue in the second.

Increasing popularity of access to city maps, evident in the first half of the 19th century resulted in new contents being included in them. They develop beyond the typical information range of general city maps. Accessibility of city maps is connected to the development of printing technology and appearance of numerous publishing houses. It is worth noting that the number of newly introduced elements of contents was relatively small - small, but significantly extending the range of information about the city, including immaterial phenomena located within city limits. Their significance refers both to the historical description of the state of the city and its development and to learning about the specifics and development of old city maps of Warsaw.

The list of elements of thematic contents concerning offices, services and transportation presented in table 2 constitutes a closed set of issues included on the analyzed city maps of Warsaw from the first three quarters of the 19th century.

Information presented in the second column of the table is an attempt to show extra-material contents related to the signs visible on city maps. Analyzing them within this discussion seems plausible, for is the essence of presentation of the police station in pointing out the building itself? It rather seems that it is human activity related to such site.

Information about interesting objects and activities was presented in three ways which can be differentiated according to their level of advancement of graphic information. Firstly, information can be placed in marginal content. It is not given directly on the map, however I list it as a method of placing information on the

\footnotetext{
12 This suggestion was expressed in 2017 by Małgorzata Mycielska in a discussion on I. Hoppe's city plan with the author of the article.
}

Table 2. Material and immaterial elements of contents on old city maps of Warsaw

\begin{tabular}{|l|l|}
\hline \multicolumn{1}{|c|}{$\begin{array}{c}\text { Elements of material } \\
\text { contents }\end{array}$} & \multicolumn{1}{c|}{$\begin{array}{c}\text { Elements of extra- } \\
\text {-material contents }\end{array}$} \\
\hline $\begin{array}{l}\text { Mail boxes } \\
\text { Post offices }\end{array}$ & $\begin{array}{l}\text { activity of post offices } \\
\text { at a particular location } \\
\text { activity of telegraph } \\
\text { stations } \\
\text { at a particular location }\end{array}$ \\
\hline \multicolumn{2}{|c|}{ Police } \\
\hline Police stations & $\begin{array}{l}\text { activity of police stations } \\
\text { at a particular location }\end{array}$ \\
\hline \multicolumn{2}{|c|}{ Courts } \\
\hline $\begin{array}{l}\text { Offices of Courts of } \\
\text { Peace }\end{array}$ & $\begin{array}{l}\text { activity of courts } \\
\text { of peace } \\
\text { at a particular location }\end{array}$ \\
\hline \multicolumn{2}{|c|}{ Transportation } \\
\hline Railroads & railroad connections \\
\hline Railroad stations & station activity \\
\hline Horse railroads & $\begin{array}{l}\text { horse railway } \\
\text { railroad connections }\end{array}$ \\
\hline Horse railroad stations & station activity \\
\hline Tramways & tram connections \\
\hline Tramway stations & station activity \\
\hline Suburban railroads & railroad connections \\
\hline Suburban railroad & station activity \\
\hline
\end{tabular}

map sheet, although outside of the cartographic picture. The indexed information in such cases contains object definition and address data street and mortgage number. Descriptive form can be seen i.a. on Wilhelm Kolberg's city maps $^{13}$, which include addresses of police stations and courts of peace. Presentation of police stations and courts of peace may seem dubious, because the referent of this presentation may be perceived as connected not to the institution, but rather to its site. However it seems plausible to assume that the site exists only if the institution is active within it, and it is this activity which determines its presentation.

\footnotetext{
${ }^{13}$ An example city map by this author is Plan Warszawy (The city map of Warsaw), 1:17,300 (800 fathoms $-8 \mathrm{~cm}$ ), 1848 , published by Wilhelm Kolberg, engraved by Józef Herkner, printed by Stanisław Strąbski, litography, known copies hand coloured.
} 
The second form of presenting the discussed information was graphic distinction of objects - institutions on the city map with a description of their purpose. In this solution outlines of selected buildings were distinguished using mainly visual variable of brightness or grain. This solution, quite popular on the old city maps of Warsaw, was used i.a. by the City Engineering Service $^{14}$ which in addition to a typical topographic sign also used description, e.g. Stacja Towarowa Drogi Żelaznej Warszawsko-Wiedeńskiej (Cargo Station of the Warsaw-Vienna Railroad), Stacja Drogi Żelaznej Warszawsko-wiedeńskiej, (Station of the Warsaw-Vienna Railroad), Stacja Czasowa Drogi Żelaznej Nadwiślańskiej (Temporary Station of the Vistula Bank Railroad). Definitions quoted from the city map, similarly to the police stations and courts mentioned above, indicate how objects function and therefore show immaterial referents of the sign used. On the City Engineering Service's plan there are no separate signs illustrating particular functions.

The third group are conventional signs. Here signs do not show the outline of the object as in the above examples. Signs are sometimes complemented with additional information, e.g. names of stations. Most signs are in the shape of geometric figures, and the relation of the sign shape and its referent is not that of similarity. This geometrizing approach is not fully consistent. Signs which relate to postal service often refer to direct associations with a post horn. Generalized images of a horn were used on city maps, in different sizes and at various levels of generalization.

Connection of the above presentations to the development of reproduction technology is justified if we analyze when certain phenomena started to be presented. Signs of courts of peace founded in the Duchy of Warsaw in 1808 were presented on city maps only since the 1890 s. Presentation of telegraph lines started in the 1880 s, although the first telegraph station in the city was founded in 1853. Discrepancies

\footnotetext{
${ }^{14}$ Plan $m$. Warszawy poprawiony $i$ dopełniony przez Służbę Inżynierską Miasta. План г. Варшавы исправлен и пополнен Городскою Инжененрною Службою, (City map of Warsaw, amended and supplemented by the Municipal Engineering Corps) 1:16,800,1879, Municipal Engineering Corps, Władysław Główczewski, litography, $51.5 \times 65.5 \mathrm{~cm}$.
}

in these dates instill the search for additional reasons for presenting them on city maps. Railroads were treated differently, however they were presented more as a topographic object than an illustration of potential travel from and to Warsaw. It is understood in the context of physiognomic features of railroads and railroad infrastructure, and such presentations should probably not be linked to an attempt at illustrating extra-material aspects of the existence of railroad objects. And these include railroad connections understood as activity, or a possibility of activity, rather than the physically existing railroad line (tracks). This aspect of existence and functioning of transportation lines seems to justify also the inclusion of horse railroads (since 1866) and horse tramways (since 1881) in the group of extra-material attributes. The question about contents of the message on a city map remains valid - is it a concrete documentation of the location of transportation objects, or is it an indication of the routes of movement of public transportation vehicles.

Legends of city maps published by the Warsaw publishing house - lithographic workshop of Feliks Kasprzykiewicz (fig. 3) are an example illustrations of the presentation methods of the objects and phenomena discussed in this section.

The share of plans including signalized information is presented in figure 4. For comparison I present one element which was unmarked in the discussed period - hospitals. Surprisingly, they only appear on city maps in the 20th century. Earlier, and especially in the 18th century, they were marked only in the case of more prominent buildings. Indexes for P.R. Tirregaille's map of 1762 and G.L. Le Rouge's from 1768 can serve as examples here.

\subsection{Property and administration.}

Property and administrative borders were some of the earliest extra-material elements presented on old city maps of Warsaw. Although on the oldest city maps by I. Hoppe (1641) and E. Dahlberg (1655) city limits are marked by earth "King Sigismund's embankments", material by all means, and by city walls, but M. Deutsch's city map of 1777 presents completely immaterial borders, invisible in real life (A. Jankiewicz 


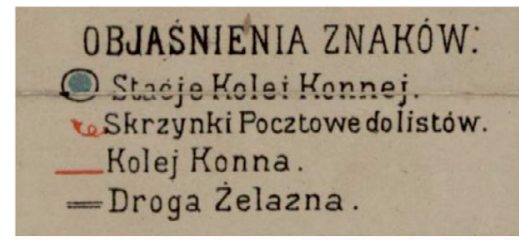

1885

\begin{tabular}{|c|c|}
\hline $\begin{array}{l}\text { ОБЪЯСНЕНIE } \\
\text { OBJAŚNIENIE }\end{array}$ & $\begin{array}{l}\text { ЗЧАКОВВ } \\
Z \text { ZNAKÓW }\end{array}$ \\
\hline  & $\begin{array}{l}\text { Cyrkuły } \\
\text { Sady Pokoju } \\
\text { Odziały Pocztowe } \\
\text { Sikrzynki Pocztowe } \\
\text { Stacye Telegraficzne } \\
\text { Stacye Kolei Konnych } \\
\text { Sieć Kolei Konnych } \\
\text { Siec Dróg Zelaznych }\end{array}$ \\
\hline
\end{tabular}

1885

\begin{tabular}{|c|c|}
\hline $\begin{array}{l}\text { ОБЪЯСНЕНIE } \\
\text { OBJAŚ NIENIE }\end{array}$ & $\begin{array}{l}\text { ЗНАКОВ } \\
\text { ZNAKÓW }\end{array}$ \\
\hline = Поличейскіе участки & Cyrkuły \\
\hline - Почтовыя Отдьленія & Odziały Pocztowe \\
\hline ш Почтовые Ящики & Skrzynki Pocztowe \\
\hline А Станцін Телеграфовь & Stacye Telegraficzne \\
\hline - Станціи Конно-Жел.Дор. & Stacye Kolei Konnych \\
\hline ..... Сьть Конно-Жел.Дар. & Sieć Kolei Konnych \\
\hline$=$ Сьть Жельзныхъ Дор: & Siec Drog Żelaznych \\
\hline
\end{tabular}

1895

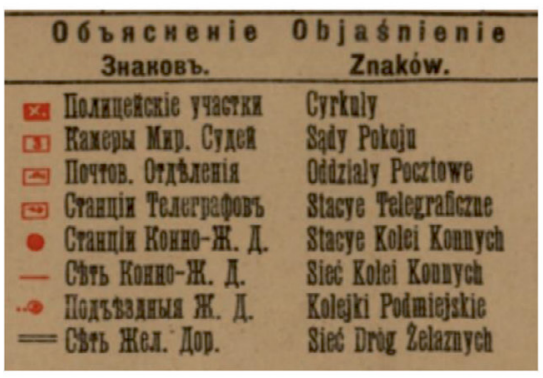

1903

Fig. 3. Legends of selected city maps of Warsaw produced by F. Kasprzykiewicz

1999). Earlier still, in 1762 P.R. Tirregaille ${ }^{15}$ applied letter designations related to the area to roughly present administrative division.

15 Plan de la ville Varsovie dedié á S.M. Auguste III Roi de Pologne electeur de Saxe etc. levé par ordre de S.E.M. le Comte Bielinski Grand Maréchal de la Couronne par M.P. Ricaud Tirregaille leut Colonel et Ingenieur au Service du Roi et de la Republique en 1762, approx. 1:6690 (1000 Polish ells - $89 \mathrm{~mm}), 1762$, Pierre Ricaud de Tirregaille, engraved by Gottlob Jakob Marstaller (Teofil Jakub Marstalski), copperplate, $132 \times 101 \mathrm{~cm}$.
However, he did not show precise course of the borders, only assigning letters to particular jurisdictions. Borders were presented according to their current location. Only on W.B. Clarke's ${ }^{16}$ city map of 1831 current and past borders of 1762 are presented. This solution seems to introduce city cartography of Warsaw into the period of presentation of thematic issues on general geographic city maps. Considering such presentation of city borders as an case of immaterial issues may seem questionable because of the existence of sanitary-police embankment, so called "Lubomirski's embankment" constructed in 1770. However in this case the character of the object is doubled, for an earth embankment is a "materialization" of an administrative idea. However other administrative objects, districts created by the decision of Sejm Czteroletni (4-year Parliament) in 1791 were completely immaterial. They were presented since 1831, either with outlining the border with a linear sign, often hand coloured or, later, printed lithographically in colour. Examples of such presentations can be seen on the maps prepared by Juliusz Kolberg in $1827^{17}$ and his son Wilhelm Kolberg which were published since 1846. In 1831 Ludwik Scaupe ${ }^{18}$ used another solution, by using different colour for buildings of particular districts, leaving the unbuilt area uncoloured. W. Kolberg and F. Kasprzykiewicz on their multi-coloured lithographic city maps used uniform color for the whole area of districts, irrespectively if built-up or unbuilt.

Presentation of districts on the city map of Warsaw was supplemented with marking them with Roman numerals, both on the map and in the legend. Some city maps show district numbers without showing their limits. Such solution

${ }^{16}$ Warsaw (Warszawa), approx. 1:16,700 (1000 French meters $-6 \mathrm{~cm}$ ), 1831, W.B. Clarke, engraved by T.E. Nicholson, published by Baldwin and Cradock, litography, known copies hand coloured, $41.7 \times 34.0 \mathrm{~cm}$.

17 Plan Warszawy (The City Map of Warsaw), approx. 1:20,000, Juliusz Kolberg, Instytut Litograficzny Szkolny (School Litographic Institute), drawn by Wilhelm Ruchacz, Warszawa 1827 (according to the city map by the General Qurtermaster Corps of the Polish Army, 1820), lithography, $51 \times 42 \mathrm{~cm}$.

18 Situacions - Plan Warsaw nach der Aufname des Russisch Polnischen General Quatermeister Stabesgezeichnet von L. Scaupae Premier Lieutnant in. der Königl. Preussisch Sechsten Artillerie Brigade 1831, approx. 1:13,500 (5000 Rhl. Fuss $-11.6 \mathrm{~cm}), 1831$, L. Scaupae, engraved by W. Steinmetz, litography, known copies hand coloured, $50 \times 77 \mathrm{~cm}$. 


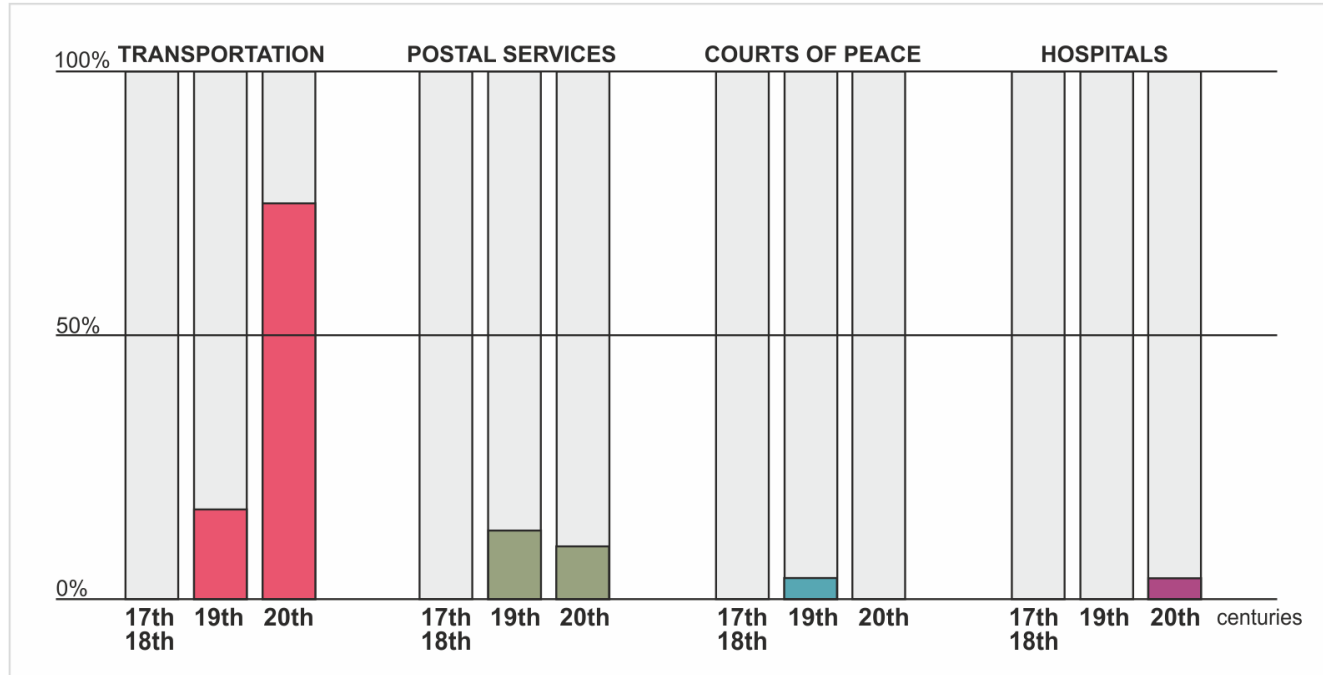

Fig. 4. Percentage of the city maps of Warsaw presenting information about services and offices in the total number of city maps in three periods

can be observed e.g. on maps by J. Glücksberg $^{19}$ from 1831 and K. Richter from $1842^{20}$.

Property issues can be observed on city maps of Warsaw since 1809. In that year the numbering of some properties, introduced in 1784 , was first presented on a city map (partial presentation of only some numbers probably results from the graphic capacity of the plan), however without showing precise property borders. Later property numbers were presented on plans prepared by the Military Engineers' Corps and their followers.

Inclusion of administrative and property contents was a characteristic feature of Warsaw city maps from the second quarter of the 19th century to the beginning of the 20th century. Presentation of administrative borders can be observed on city maps published by commercial publishers, such as these owned by F. Kasprzykiewicz, O. Fleck and W. Walkiewicz.

19 Plan ogólny miasta Stołecznego Warszawy z wyszczególnieniem Cyrkułów, Ulic i znacznieyszych zabudowań. Plan général de la Ville de Varsovie avec la designation des Arondissements des rues, et des principaux edifiees, 1832, Jan Glücksberg, litography, $36 \times 25 \mathrm{~cm}$.

20 Планъ города Варшавы, арprox. 1:17,000, survey Karol Richter, engraved by Koniew, Kamkin, Sorokin, text engraved by Ergarb, Warszawa 1842 (according to the city map by the General Qurtermaster Corps of the Polish Army, 1820), copperplate, $53 \times 43 \mathrm{~cm}$.
Property numbering can be seen on military and official elaborations. The share of city maps containing property and administrative information is illustrated in figure 5 .

Summing up the topic of presentation of administrative and property issues one can conclude that they were shown with so-called letter or numeral signs, linear signs or colour areas. Cartographic information was often supplemented with captions which identified the symbolic image. Property division concerning both single properties and larger areas were presented with lines and by relating captions (property number and district name) to particular areas. All the phenomena in this group can be clearly categorized as immaterial or extra-material.

\section{Conclusions}

The research hypothesis that on the example of city plans of Warsaw a successive increase of the number, and therefore also of the role, of extra-material elements can be observed, although it is impossible to indicate a clear beginning of their presentation, has not been fully confirmed for the entirety of the presented phenomena, basing on the research conducted. 


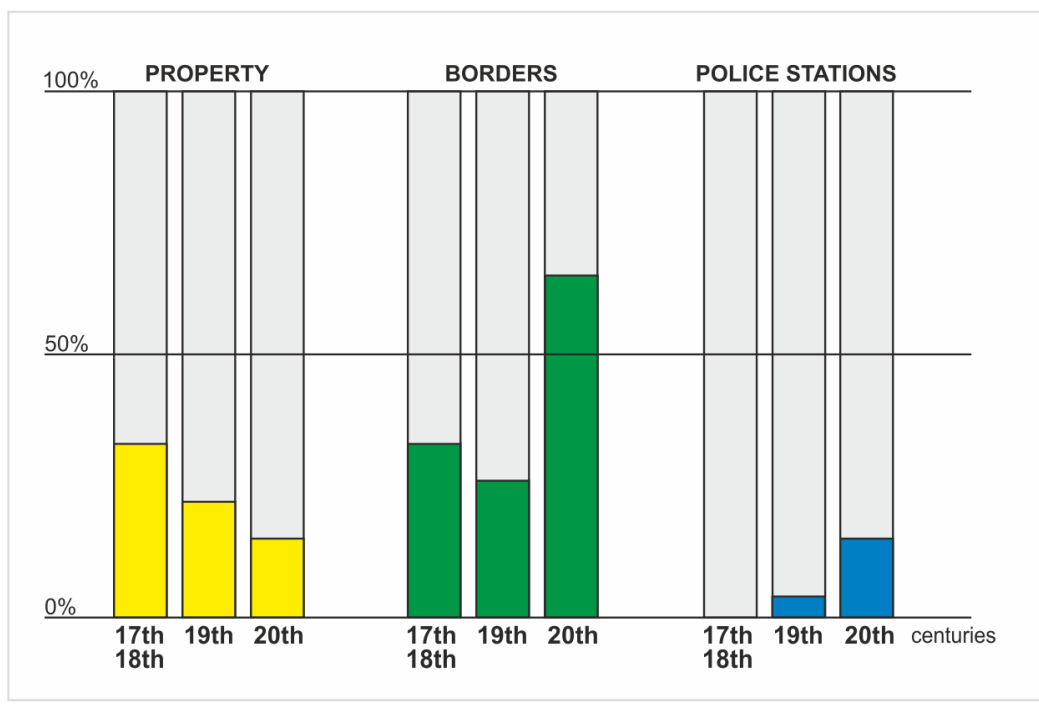

Fig. 5. Percentage of the city maps of Warsaw presenting property and administrative information in the total number of city maps in three periods

Different phenomena were differently presented on different maps in different periods. Only in the case of some elements constant tendencies of increasing number and significance can be observed (e.g. street and area names, transportation and city visions).

\section{Literature}

Bartoszewicz H., Weszpiński P.E., 2017, Korpus Inżynierów Wojskowych. Plan Warszawy 1825. Ze zbiorów kartograficznych Muzeum Warszawy. Warszawa: Muzeum Warszawy.

Handke K., 2011, Dzieje Warszawy nazwami pisane. „Biblioteka Warszawska”, Warszawa: Muzeum Historyczne m.st. Warszawy.

Jankiewicz A., Weszpiński P.E., Witecki M., 1999, Atlas Historyczny Warszawy. Warszawa: Archiwum Państwowe m.st. Warszawy, Miasto Stołeczne Warszawa, Wojewoda Mazowiecki.

Karczewski A., [1945], Plany Warszawy w XVIII i początku XIX do czasów Księstwa Warszawskiego włącznie. Typesctript from a collection of the State Archives in Warsaw.

Krassowski B., Majewska B., 1980, Plany Warszawy 1655-1814. Warszawa: Biblioteka Narodowa.

Olsen B., 2013, W obronie rzeczy. Archeologia i ontologia przedmiotów. Warszawa, Instytut Badań Literac-
In many cases differentiation of presentation between material and immaterial elements may seem unclear. However all the discussed or quoted cases bear qualities of immaterial elements and have been cartographically presented as such.

kich (original edition: 2010, In Defense of Things. Archeology and the Ontology of Objects. Lanham, New York, Toronto, Plymouth, AltaMira Press).

Weszpiński P.E., 2012, Dawne źródła kartograficzne do poznania nazewnictwa miejskiego Warszawy od XVII do XIX wieku. In: Śladami nazw miejskich Warszawy. Z prac Zespołu Nazewnictwa Miejskiego. „Biblioteka Warszawska”, Warszawa: MHW, pp. $15-38$.

Weszpiński P.E., 2013, Plan miasta Warszawy. Plan von der Stadt Warschau 1808-1809. „Kronika Warszawy" Nr 1(148)/2013, pp. 100-105.

Weszpiński P.E., 2014, Dzieje i analiza dawnych planów Warszawy. Doctors dissertation. Warszawa: Wydział Geografii i Studiów Regionalnych Uniwersytetu Warszawskiego.

Zarębska T., 1964, Plan Warszawy z pierwszej połowy XVII w. „Kwartalnik Architektury i Urbanistyki” T. 9, nr 1, pp. 233-254. 